\title{
An Influence of Contact Surface Wetting on Wall Slip in a Flow of Molten Polymer
}

\author{
Yoshiaki $\mathrm{KANOH}^{* 1 * 2}$, Takayuki Shbata ${ }^{* 1}$, Hiromoto Usur ${ }^{* 2}$, Shigeru YAO ${ }^{* 1}$, \\ and Tatsuya SHoJI ${ }^{*}$
}

*1 Corporate Research \& Development Division,

Ube Industries, Ltd., 1980 Okinoyama Kogushi, Ube-city, 755, Japan

*2 Department of Applied Chemistry and Chemical Engineering,

Yamaguchi University, 2557 Tokiwadai, Ube-city, 755, Japan

The contact angle between solid surface and molten polymer was measured by a sessile drop method. The results of contact angle measurements were compared with the wall slip velocity determined previously by the present authors. It was proved that a good correlation was observed between the wall slip velocity and the work of adhesion which was calculated by the measured contact angle. Since the larger wall slip velocity showed previously a significant improvement of the efficiency of color and/or material change-over in a blow molding process, it is concluded that we should select a surface condition which show a smaller value in work of adhesion. The conditions for smaller work of adhesion was obtained experimentally in this study.

Key Words : Wetting/Contact angle/Work of adhesion/Wall slip/

Molten polymer/Color and/or material change-over

\section{固体界面における溶融澍脂のぬれとスリップに関する研究}

\author{
加納好昭 $* 1 * 2$. 柴田貴章 ${ }^{* 1} \cdot$ 薄井洋基 ${ }^{*}$.八尾 滋*1 庄司達也 ${ }^{* 1}$
}

(原稿受理：1996年2月26日）

\section{1.腥言}

プラスチックの成形機のなかでブロー成形機は射出成形機 と比較して, ダイス等の溶融樹脂流路が長く, 複雑な形状をし ており, 色替え・樹脂替え性能が著しく劣っていると言われて いる，そのため, 従来より, 色替え・樹脂替え時には管路温度, 樹脂温度や押出速度を成形時よりも高めに設定する等経験的 な対策が行われているが, 理論的な把握, つまりダイス樹脂流 路内の溶融樹脂の流動状態の正確な把握と，それに基ついた色 替え，樹脂替え条件の適正化が図れていなかった。

そこで加納ら ${ }^{122}$ は，このように成形条件によって色替え・ 樹脂替え性能が向上するというのは，管路内壁面上ての溶融樹 脂のスリップが大きく関与し重要な鍵になっていると考えて

:1宇部興库维研究開発本部 ₹755 山口県宇部市大字小串字沖の山1980 "2山口大学工学部応用化学工学科 $\bar{\top} 755$ 山口県宇部市常盉台 2557
検討を行った．この結果, 管路温度, 樹脂温度, 押出速度およ び樹脂圧力の各因子が壁面スリップによ゙の様に影響を及ほし ているかを把握すると共に, スリップ速度の大きさは固体界面 の種類, 溶融枇脂の種類によって大きく変わることを明らかに した.

また, 従来より, 溶融樹脂によるダイス壁面のぬれは表面エ ネルギーの変化によって制御できるため, 固体表面の性質, 即 ちぬれ性を変えることによって壁面スリップの発生条件が変 わることが知られている3゙．例えば， Ramamurthy ${ }^{42}$ はポリ エチレンにおける研究でフィルム成形装置において溶融樹脂 とダイス材質を適切に選択することによって付着を抑えて, 壁 面スリップと密接な関係にあるメルトフラクチャーの発生を なくすことがでることを示した．また，Piauら ${ }^{3)}$ はフッ素 樹脂製のキャピラリーにおける壁面スリップについて研究を 
行った. 更に彼らは，ステンレス製のオリフィス表面に滑り止 めをコーティングしたものを使用してオリフィスにおける壁 面スリップについて研究を行った. しかしながら、これらの研 究では, 壁面でのぬれ性とスリップ速度の関連性について定量 的な検証がなされていなかった。

本報ては，溶融樹脂と管路内壁面のぬれ性が壁面スリップと 何らかの関係があるという仮定のもとて，各種溶融樹脂，固体 界面毎に，固体界面と溶融樹脂間のぬれ角度を我々の考案した 方法で計測した．更に，このぬれ角度から付着仕事を算定して， 壁面での性とスリップ速度の関連性について考察を行っ た. 以下にその研究結果を報告する.

\section{2. 実的}

固体界面之溶融樹脂間のぬれ性を検討するため, ぬれ角度を

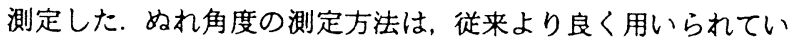
る液滴法を用い ${ }^{5}$ ，平滑な固体表面に置いた液滴の形状から 液滴の高さと底面の最大径を読み取り，角度に換算して求めた。

測定装置はFig. 1 に示すような自作のぬれ角度测定装置を 使用した．妒内に金属のテストプレート，その上に䛧脂ペレッ ト片を配置し，所定の温度まて加熱，保持した，柜内は，テス トプレート近くに設置された熱電対によって妒内温度をモ二 ターして所定の温度になる様に温度調節を行った. テストプレ 一ト上の樹脂ペレット片が溶融時に酸化されることを防ぐた めに窒素ガス雾囲気で加熱した。

樹脂ペレット片は加熱することにより溶融して液滴状態に なるが，その液滴形状を以下に述へる方法で側面から撮影する ことで金属固体表面上における溶融樹脂のぬれ角度の測定を 行った. 光源としてはHe-Neレーザーを用いた.レーザー発 生装置から発生したレーザー光は偏光レンズを通過し, 拡大レ ンズによって直径を約 $3 \mathrm{~mm}$ から $8 \mathrm{~mm}$ へと拡大されて炉内のテ ストプレート上の樹脂ペレット片に照射される.この照射によ って生じる影をズームアップレンズで拡大してスクリーン上 に像を結ばせ，この映像をC C D カメラで撮影した. 同時にモ ニター画面上で液滴の外形を確認し，この外形が変化しなくな ったところで実験を終了した。

Furnace containing molten polymer droplet on the heating plate

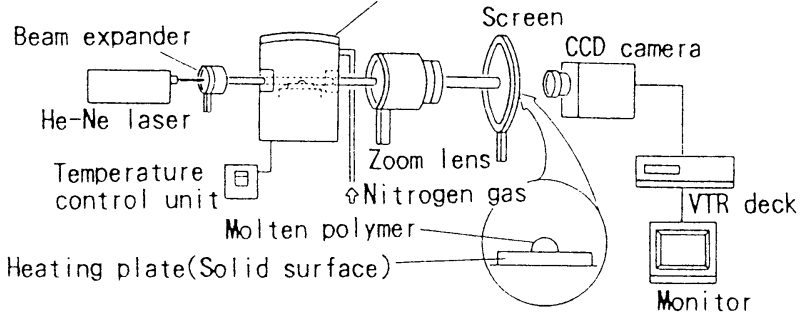

Fig. 1 Schematic drawing of experimental device for the contact angle measurement
テストプレートは大きさが $10 \mathrm{~mm}$ (綐) $\times 10 \mathrm{~mm}$ （横） $\times 3 \mathrm{~mm}($ 厚 さ），炭素鋼製の金属片て，テスト表面はTable I に示す様に 加納ら ${ }^{2)}$ が壁面スリップの研究に使用した管路の壁面と同し 炭素龬（ $\mathrm{R} \max 0.4 \mu \mathrm{m} ）$ ，炭素鋼 $(\mathrm{R} \max 1.6 \mu \mathrm{m})$ ，フッ素 樹脂コーティング ( P T F E コーティング)，クロムメッキの 4 種類を使用した．尚，フッ素樹脂コーティング，クロムメッ キは炭素銅（ $\mathrm{R} \max 0.4 \mu \mathrm{m}$ ）のプレート上に施している.

また、樹脂ペレットはTable IIに示す様に加納ら ${ }^{2)}$ が壁面 スリップの研究に使用した樹脂と同じ高密度ポリエチレン: H D P E（チッソ製 B812），ポリプロピレン：P P（宇部 興産製 B301H），ポリカーボネート：PC（GE製 LEXAN EBL2061）の3 種類を使用した．今回の実験ては，樹脂ペレッ ト片は重量が2.5〜2.7mgの角柱形状になる様にカットし, 長手 方向がプレートに対して垂直に直立する様にテストプレート 上に置いた。

尚、実験によって得られた画像デー夕は画像処理装置( P I A S 製 LA-555）に取り込んてモニター画面上で静止画 とし，画像処理装置に付属している静止画像内て角度を測定す るプログラムを用いてぬれ角度を求めた。

Table I Solid surface used in this study

\begin{tabular}{|c|l|}
\hline Channel & \multicolumn{1}{|c|}{ Solid surface conditions } \\
\hline$a$ & $\begin{array}{l}\text { Steel (non-coating), } \\
\text { Max. he ight of irregularities(Rmax) } *: 0.4 \mu \mathrm{m}\end{array}$ \\
\hline$b$ & $\begin{array}{l}\text { Steel (non-coat ing). } \\
\text { Max. height of irregularities(Rmax) } *: 1.6 \mu \mathrm{m}\end{array}$ \\
\hline$c$ & $\begin{array}{l}\text { Fluoride resin coating(coating thickness: } 30 \mu \mathrm{m}), \\
\text { Max. height of irregularities(Rmax) } *: 3.1 \mu \mathrm{m}\end{array}$ \\
\hline$d$ & $\begin{array}{l}\text { Chromium plat ing(plating thickness: } 30 \mu \mathrm{m}) . \\
\text { Max.height of irregularities(Rmax) } \neq: 0.2 \mu \mathrm{m}\end{array}$ \\
\hline
\end{tabular}

* Rmax indicates the leveling gap between top and bottom of surface roughness wave along standard length on the cross-section.

Table II Resin used in this study

\begin{tabular}{|c|c|}
\hline Resin & Molding Temperature $\left({ }^{\circ} \mathrm{C}\right)$ (Standard) \\
\hline HDPE $*$ (CHISSO B812) & 200 \\
\hline$P P \quad \#$ (UBE B301H) & 230 \\
\hline$P C 末 *$ (GE LEXAN EBL2061) & 260 \\
\hline
\end{tabular}

* HDPE $=$ High density polyethylene

\# PP = Polypropylene

\#* PC = Polycarbonate 


\section{3. 䊅果と考察}

加納ら ${ }^{2)}$ が壁面スリップの研究に使用した枇脂のうち H D P Eのぬれ角度については楥和時間が長く今回は測定て きなかったが, その他の 2 種類の溶融樹脂，4種類の固体界面 毎にぬれ角度 $\theta$ (degree)を測定した. Fig. 2 (1) にぬれ角度 $\theta$ の測定結果を,Fig. 2（2）にこれより計算した付着仕事 $\mathrm{W}_{\mathrm{A}}\left(\mathrm{mJ} / \mathrm{m}^{2}\right)$ を示す. 尚, 付着仕事 $\mathrm{W}_{\mathrm{A}}$ は, 液体が液滴として固 体面上に付着する場合の付着ぬれてのエネルギ一変化を表し， 次式で与えられる ${ }^{5}$.

$$
\mathrm{W}_{\mathrm{A}}=\gamma_{s \mathrm{v}}+\gamma_{\mathrm{LV}}-\gamma_{\mathrm{sL}}
$$

また, 液体, 固体, 気体の各界面ではYoung によって導かれた 次の関係式て釣り合っている ${ }^{5)}$.

$$
\gamma_{S v}-\gamma_{S L}=\gamma_{L V} \cdot \cos \theta
$$

(1)，（2）式より

$$
\mathrm{W}_{\mathrm{A}}=\gamma_{\mathrm{LV}}(1+\cos \theta)
$$

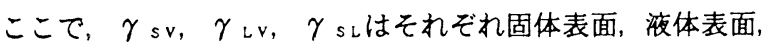
固液界面でのエネルギー $\left(\mathrm{mJ} / \mathrm{m}^{2}\right)$ を表す. 液体表面でのエネル ギー $\gamma_{\text {Lvは八尾ら }}{ }^{6)}$ の, 常温ての表面張力, 比容と任意の温 度における比容との関係から溶融温度における高分子の表面 張力を推算するという手法で計算した. 今回使用した値は, P P (230て)では $18.8 \mathrm{~mJ} / \mathrm{m}^{2} ， \mathrm{P} \mathrm{C}(260 乞) て ゙ 29.0 \mathrm{~mJ} / \mathrm{m}^{2}$ であ る. 尚，今回のぬれ角度の測定ては，妒内を窒素ガス雾用気に して加熱しているが, ペレット片が溶融して安定した液滴状態 になるまてには 1 時間程度の時間を要しており，GＰＣ測定に より樹脂の劣化について確認を行った. その結果, ぬれ角度が 正常に測定できている間は樹脂の分子量の変化は見られず，梂 脂の劣化はほとんどなかったと考えられる。

固体界面と溶融樹脂間のぬれ角度の测定結果をFig. 2（1） に示す. 尚, 各测定值は試料数 5 点の相加平均値及び最大值亡 最小值を示している.ぬれ角度測定法は測定毎のばらつきが比 較的大きい測定法であるが，今回の測定では図からわかるよう に比較的安定した結果が得られた．また，樹脂がP Pの場合亡 P Cの場合では全体を通じてP P の方が角度が小さくな っており，これは各々の表面張力の大きさから考えても妥当性 のあるものでる. 以上の結果から，今回用いた手法は今まて にない新規なものであが, 溶融樹脂と金属等の固体界面との 界面相互作用力の測定に有効なものであることがわかる. 固体 表面の材質，表面粗さの影響については，フッ素樹脂コーティ ングの場合と炭素鋼 ( $\mathrm{R} \max 0.4 \mu \mathrm{m}$ )の場合で, ぬれ角度が大き く,クロムメッキの場合と炭素鋼 $(R \max 1.6 \mu \mathrm{m})$ の場合では, ぬれ角度が小さなった。

また，付着仕事の算定結果をFig. 2（2）に示す. 同一の溶 融樹脂の中で固体界面を䒜えた時, ぬれ角度が大きいほど付着 仕事は小さくなっている，一方，溶融樹脂別ては，PCの場合， ぬれ角度はP P と比較して全体的に大きな值を示しているに もかかわらず, 溶融樹脂の表面エネルギーがP P に比へるとは るかに大きいため，付着仕事は大きな值を示している（）（3） 式から判る様に, 付着仕事 $W_{A}$ は好角度 $\theta$ と溶融樹脂の表面
エネルギー $\gamma$ しvの関数になっており，溶融樹脂の表面エネル ギーの影㹕度合いがかなりきいということが判る。
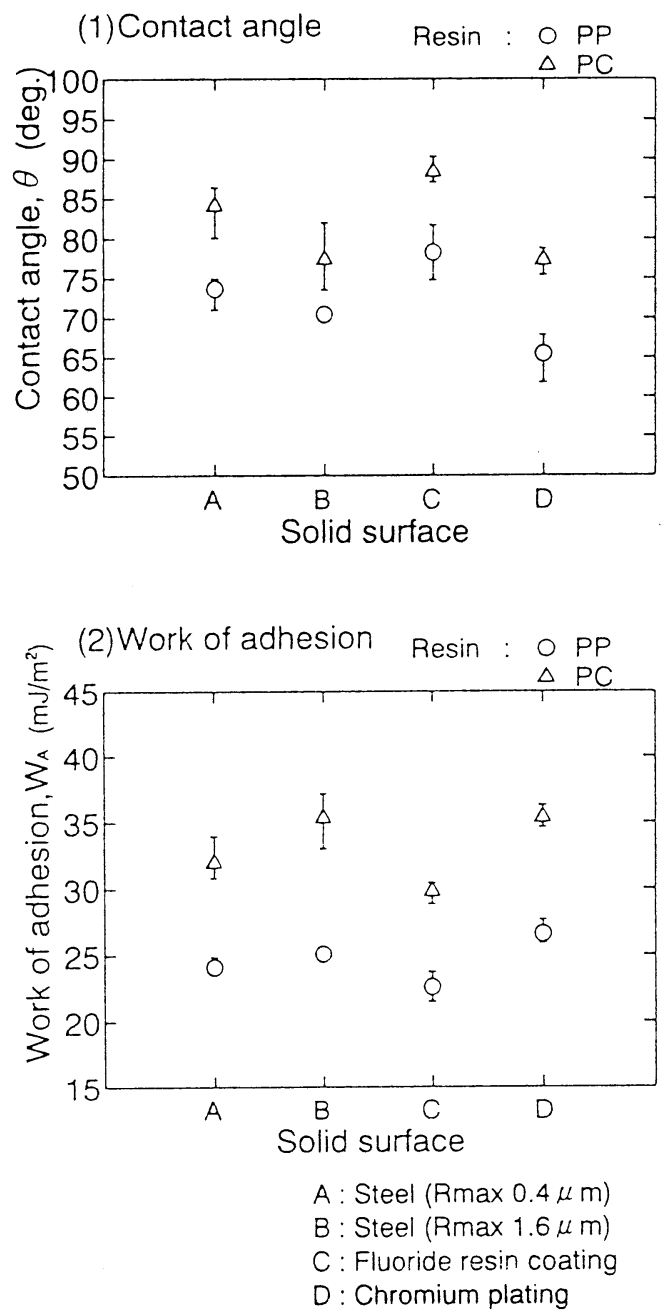

Fig. 2 Contact angle and work of adhesion

次に，壁面でのスリップ速度の測定結果について述へる．ス リップ速度の測定に使用した可視化実験装置, 実験方法及び測

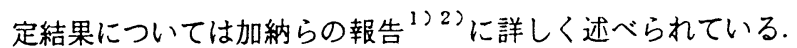
尚, これらの報告の中で, 決定されたスリップ速度を用いて計 算した速度分布は実験テータと比較してみると良く一致する ことが述へらられている.この結果, 固体界面の表面状態, 種類 や樹脂種類とスリップ速度の関係については以下の通りであ った. 樹脂種類についてはスリップ速度の大きい順にP P , P C, H D P E となり, 特に, P P は全体的に P C, H D P E よりスリップ速度が大きくなった，固体界面の種類，表面状態 については壁面がフッ素樹脂コーティングや炭素鋼 （ $\mathrm{R} \max$ $0.4 \mu \mathrm{m}$ ） の時スリップ速度が大きく，クロムメッキや炭素鋼 （Rmax $1.6 \mu \mathrm{m} ）$ のときはスリップ速度が小さいという傾向 があった. 
Table III Contact angle, work of adhesion and slip velocity

\begin{tabular}{|c|c|c|c|c|c|c|}
\hline Molten polymer & \multicolumn{3}{|c|}{$\operatorname{PP}\left(230^{\circ} \mathrm{C}\right) *$} & \multicolumn{3}{|c|}{$\mathrm{PC}\left(260^{\circ} \mathrm{C}\right) *$} \\
\hline $\begin{array}{l}\text { Solid surface } \\
\text { conditions }\end{array}$ & $\begin{array}{l}\text { Contact } \\
\text { angle } \\
\text { (deg. ) }\end{array}$ & $\begin{array}{l}\text { Work of } \\
\text { adhes ion } \\
\left(\mathrm{mJ} / \mathrm{m}^{2}\right)\end{array}$ & $\begin{array}{l}\text { Slip velocity } \\
(\mathrm{cm} / \mathrm{s})\end{array}$ & $\begin{array}{l}\text { Contact } \\
\text { angle } \\
\text { (deg. ) }\end{array}$ & $\begin{array}{l}\text { Work of } \\
\text { adhesion } \\
\left(\mathrm{mJ} / \mathrm{m}^{2}\right)\end{array}$ & $\begin{array}{c}\text { Slip velocity } \\
(\mathrm{cm} / \mathrm{s})\end{array}$ \\
\hline $\begin{array}{l}\text { Steel(non-coating) } \\
\quad \operatorname{Rmax} 0.4 \mu \mathrm{m}\end{array}$ & 74 & 24 & 1.03 & 84 & 32 & 0.48 \\
\hline $\begin{array}{l}\text { Steel(non-coating) } \\
\quad \operatorname{Rmax} 1.6 \mu \mathrm{m}\end{array}$ & 70 & 25 & 0.65 & 77 & 36 & 0.21 \\
\hline Fluoride resin coating & 78 & 23 & 0.97 & 88 & 30 & 0.57 \\
\hline Chromium plating & 66 & 26 & 0.73 & 77 & 36 & - \\
\hline
\end{tabular}

* The resin temperature was set equal to solid surface temperature.

* Test condition; Wall temperature: Standard(Molding temperature)

Extrusion rate : Middle

以上より，ぬれ角度，付着仕事の各テスト毎の相加平均値及 びその時のスリップ速度の結果をTable III に示す.これらの関 係をわかりやすくするために，ぬれ角度とスリップ速度，付着 仕事とスリップ速度のそれぞれの相関係数を求めた. Table IIIに示したテスト条件の場合のぬれ角度とスリップ速度の関 係をFig. 3 に示す. この時のP P と P C 全体における相関係数 は，0.29と低く，相関性はほとんどないが，P Pだけについて 相関係数を求めると0.77, P Cだけについて相関係数を求める と0.99と高く，樹脂を固定して考えると高い相関性があると思 われる. 同様に, Table IIIに示したテスト条件の場合の付着仕 事とスリップ速度の関係をFig. 4 に示す.この時のP P とP C 全体における相関係数は，0.94と高く，付着仕事とスリップ速 度には相関性が高いと考えられる。これは先程の考察の通り， ぬれ角度よりも溶融樹脂の影慗度合いが大きい付着仕事の方 がスリップ速度との相関性が高いためと考えられる. 以上のこ とから, 溶融樹脂についてはP Cよりも付着仕事の小さい P P の方がスリップ速度が大きく, また, 固体界面についてはクロ ムメッキや炭素鋼（ $\mathrm{R} \max 1.6 \mu \mathrm{m}$ ) よりも付着仕事の小さい> ッ素樹脂コーティングや炭素鎆（ $\mathrm{R} \max 0.4 \mu \mathrm{m}$ ) の方がスリッ プ速度が大きいという傾向があり，付着仕事を指標として考え た壁面でのぬれ性とスリップ速度には相関性が高いと考えら れる.

今回, 溶融樹脂と管路内壁面のぬれ性が，壁面スリップと何 らかの関係があるのではないかという仮定のもとで実験を行 ったが, 以上のように，その仮定の妥当性を襄付ける結果が得 られた.

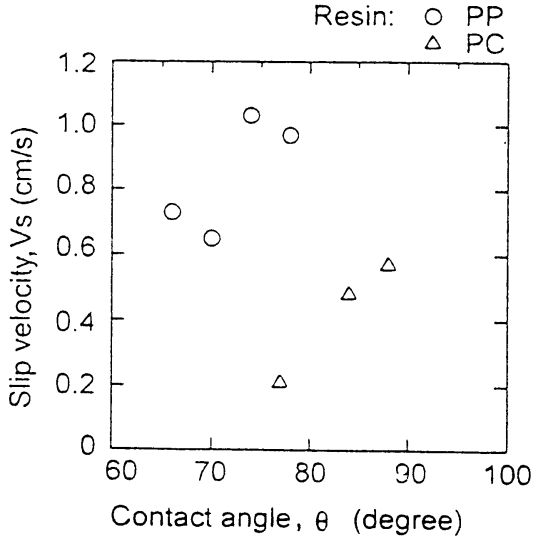

Fig. 3 Relationship between contact angle and slip velocity

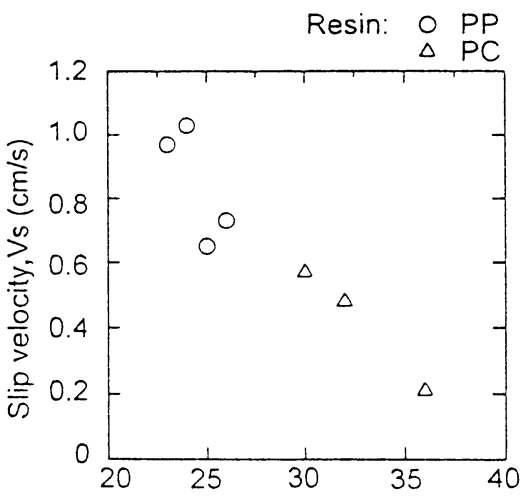

Work of adhesion, $W_{A}\left(\mathrm{~mJ} / \mathrm{m}^{2}\right)$

Fig. 4 Relationship between work of adhesion and slip velocity 


\section{4. 結}

固体界面と溶融樹脂間のぬれ角度を測定し, 壁面スリップ速 度の測定結果と比較した結果，以下の知見を得た。

(1)固体界面之溶融樹脂間のぬれ角度を計測した結果, 救脂を P P とした実験では，全体的にP Cよりもぬれ角度が小さ くなった，管路内表面の材質，表面粗さの影響は, フッ素 梂脂コーティング，炭素鋼( $\mathrm{R} \max 0.4 \mu \mathrm{m})$ の坦合，ぬれ角 度が大きく、クロムメッキ, 炭素銅 $(R \max 1.6 \mu \mathrm{m})$ の場合， ぬれ角度が小さくなった。

(2)これらのぬれ角度から算定した付着仕事とスリップ速度 の測定結果を比較した結果, 付着仕事が小さいほどスリッ プ速度が大きくなるという傾向があり，付着仕事を指標と して考えた壁面てのぬれ性とスリップ速度には相関性が 高いと考えられる。

( 3 )以上より，救脂替え等を向上させるためには，壁面スリッ プが大きい, 即ち溶融樹脂との付着エネルギー(付着仕事) の小さい材質の管路内壁面を選定すればよいことがわか った．尚，付着仕事が小さいときの条件としては，椹脂は P P の場合で，管路内壁面は表面粗さが小さい場合かフッ 素樹脂コーティングをした場合であり,クロムメッキをし た場合は付着仕事が大きくなった。

\section{的辞}

本研究を進めるに当たり，協同て研究頂いた山口大学工学部 応用化学工学科の佐伯隆氏，川崎誠司氏，Mendra Tri S. Ri tonga 氏，並びに御協力頂いた宇部興産侏研究開発本部の 伊藤禎基氏，西村隆文氏に謝意を表します。

\section{参考文城}

1) 加納好昭, 柴田貫章, 西村隆文, 薄井洋基, 佐伯隆，日本 レオロジー学会誌掲載予定(1996).

2) 加納好昭, 柴田貫章, 西村隆文, 薄井洋基, 佐伯隆，日本 レオロジー学会第43回レオロジー討論会予稿集, p276 (1995).

3) Piau J M, Kissi N El, Trembley B, J. Non-Newtonian Fluid Mech., 34, 145(1990).

4 ) Ramamurthy A V, J. Rheol., 30,337(1986).

5 ) 高分子学会高分子表面研究会編，“高分子表面技術”, （1987），日刊工業新聞社，pl14。

6 ) 八尾流，曾根将則，亀井衛一，材料，43，354(1994). 